\title{
Shift in the chemical composition of dissolved organic matter in the Congo River network
}

\author{
Thibault Lambert ${ }^{1}$, Steven Bouillon ${ }^{2}$, François Darchambeau ${ }^{1}$, Philippe Massicotte ${ }^{3}$, and Alberto V. Borges ${ }^{1}$ \\ ${ }^{1}$ University of Liège, Chemical Oceanography Unit, Liège, Belgium \\ ${ }^{2}$ K.U. Leuven, Department of Earth and Environmental Sciences, Leuven, Belgium \\ ${ }^{3}$ Aarhus University, Department of Bioscience, Århus, Denmark \\ Correspondence to: Thibault Lambert (tlambert@ulg.ac.be)
}

Received: 3 June 2016 - Published in Biogeosciences Discuss.: 21 June 2016

Revised: 14 September 2016 - Accepted: 20 September 2016 - Published: 28 September 2016

\begin{abstract}
The processing of terrestrially derived dissolved organic matter (DOM) during downstream transport in fluvial networks is poorly understood. Here, we report a dataset of dissolved organic carbon (DOC) concentrations and DOM composition (stable carbon isotope ratios, absorption and fluorescence properties) acquired along a $1700 \mathrm{~km}$ transect in the middle reach of the Congo River basin. Samples were collected in the mainstem and its tributaries during highwater $(\mathrm{HW})$ and falling-water $(\mathrm{FW})$ periods. DOC concentrations and DOM composition along the mainstem were found to differ between the two periods because of a reduced lateral mixing between the central water masses of the Congo River and DOM-rich waters from tributaries and also likely because of a greater photodegradation during FW as water residence time (WRT) increased. Although the Cuvette Centrale wetland (one of the world's largest flooded forests) continuously releases highly aromatic DOM in streams and rivers of the Congo Basin, the downstream transport of DOM was found to result in an along-stream gradient from aromatic to aliphatic compounds. The characterization of DOM through parallel factor analysis (PARAFAC) suggests that this transition results from (1) the losses of aromatic compounds by photodegradation and (2) the production of aliphatic compounds by biological reworking of terrestrial DOM. Finally, this study highlights the critical importance of the riverfloodplain connectivity in tropical rivers in controlling DOM biogeochemistry at a large spatial scale and suggests that the degree of DOM processing during downstream transport is a function of landscape characteristics and WRT.
\end{abstract}

\section{Introduction}

Dissolved organic matter (DOM) is composed of thousands of heterogeneous compounds that differ in origin and reactivity (Leenheer and Croué, 2003) and is a central component of the global carbon cycle (Battin et al., 2008). DOM in streams and rivers mainly originates from the terrestrial ecosystem, but can also be fueled by internal sources (Bertilsson and Jones, 2003; Battin et al., 2008). Recent experimental and field studies have demonstrated that sorption, photochemical and biodegradation processes continuously degrade and transform DOM throughout fluvial networks (Massicotte and Frenette, 2011; Ward et al., 2013; Cory et al., 2014; Fasching et al., 2014; Lapierre and del Giorgio, 2014; Lambert et al., 2016). Large surveys of boreal lakes have suggested that DOM was degraded along a gradient from aromatic to aliphatic compounds and that the chemical composition of DOM was the dominant control of overall DOM reactivity (Kothawala et al., 2014; Kellerman et al., 2015). Similarly, a large survey of temperate streams and rivers has reported a preferential loss of aromatic DOM and parallel gain in aliphatic DOM with increasing stream order, resulting in a diminution of the variability in dissolved organic carbon (DOC) concentration and DOM composition from small headwater streams to large rivers (Creed et al., 2015). However, the role of environmental factors (i.e., climatic variables, water chemistry, landscape properties) on DOM transformation in fluvial networks remains poorly constrained (Massicotte and Frenette, 2011; Marín-Spiotta et al., 2014). 
The consideration of temporal dynamics in addition to the spatial dimension is poorly investigated, yet it represents a crucial step towards a better understanding of DOM transport and processing in fluvial networks. Temporal dynamics refer here to the changes of the hydrological state of catchments that occur between high-flow and low-flow periods and are susceptible to altering DOM dynamics for at least two reasons. First, the concentration, the composition and the reactivity of DOM in streams and rivers are largely determined by seasonal changes in water levels that control the hydrological connectivity between rivers and wetlands (Junk et al., 1989; Battin, 1998; Besemer et al., 2009; Osburn et al., 2009; Lambert et al., 2016). Secondly, the increase in water discharge during high-flow periods induces a decrease in water residence time (WRT) within catchments due to increasing water velocities. Beyond the role of external and intrinsic drivers on DOM degradation, WRT represents a major control that regulates the degree of DOM transformation in aquatic ecosystems (Cory et al., 2007; Battin et al., 2008; Weyhenmeyer et al., 2012). According to the recent pulse-shunt concept (Raymond et al., 2016) that builds off of the "active pipe" concept (Cole et al., 2007), the degree of DOM processing in fluvial networks should be reduced during high-flow periods as hydrological events favor the transport of DOM through the drainage network and therefore reduce the time in which dynamic processes can take place.

African tropical rivers have among the highest specific flux of DOC worldwide (Meybeck, 1993) and have an important role in the global carbon cycle (Borges et al., 2015a, b). Yet they remain largely underrepresented in large-scale studies on DOM processing. For example, only few studies have investigated DOM biogeochemistry in the Congo Basin (Spencer et al., 2010, 2012; Bouillon et al., 2012, 2014; Mann et al., 2014), despite the fact that the Congo River the largest river in Africa and the second largest river worldwide after the Amazon in terms of drainage basin area and water discharge (Laraque et al., 2009) - is the second major exporter of terrestrial organic carbon to the oceans, 85$90 \%$ being in the form of DOC (Coynel et al., 2005; Laraque et al., 2009). Downstream transport of DOM in the Congo River has not yet been investigated in the middle part of the Congo Basin where the second-largest tropical flooded forest wetland is located, the Congolese "Cuvette Centrale". Additionally, in the middle reach, the Congo River receives inputs from its major tributaries, such as the Kasai, Ruki and Oubangui (Fig. 1).

Emerging conceptual models that describe how inland waters transform DOM flowing down the fluvial network, such as the "chemostat" hypothesis (Creed et al., 2015) and the pulse-shunt concept (Raymond et al., 2016), need to be tested by empirical data acquired through extensive studies in tropical ecosystems. The Congo River and its tributaries were sampled along a $1700 \mathrm{~km}$ transect from the city of Kisangani to the city of Kinshasa during two contrasting hydrological periods (Figs. 1 and 2). DOM was character- ized through its optical properties, its stable carbon isotope composition $\left(\delta^{13} \mathrm{C}_{\mathrm{DOC}}\right)$ and its DOC concentration. Optical measurements (including absorption and fluorescence) have been underscored as an efficient tool for characterizing the source and the reactivity of specific fractions of the DOM pool at large spatial scales (Jaffé et al., 2008; Yamashita et al., 2010; Massicotte and Frenette, 2011; Cawley et al., 2012; Kothawala et al., 2014; Lambert et al., 2016), notably with the development of multicomponent deconvolution techniques such as the parallel factor analysis (PARAFAC) (Stedmon et al., 2003; Murphy et al., 2013). The aims of this study were (1) to characterize the longitudinal evolution of DOM in the Congo River in the middle reach of the basin, (2) to investigate the transformation of DOM during its downstream transport in the fluvial network and (3) to identify potential environmental drivers of DOM processing.

\section{Materials and methods}

\subsection{Study area}

The Congo is the largest river in Africa and the second largest river in the world after the Amazon in terms of drainage basin area $\left(\sim 3.7 \times 10^{6} \mathrm{~km}^{2}\right)$ and water discharge $\left(\sim 43000 \mathrm{~m}^{3} \mathrm{~s}^{-1}\right)$ (Laraque et al., 2009). The river originates in the southeastern part of the basin and is called the Lualaba until it crosses the city of Kisangani, after which it becomes known as the Congo. The Congo Basin straddles the Equator, with major tributaries located in both hemispheres (Fig. 1). Thus, the rainy season on the northern part is compensated for by the dry season on the southern part, and vice versa. Consequently, seasonal water height variations are largely attenuated (Runge, 2008), in stark contrast with the Amazon river, leading to marked differences in biogeochemistry (e.g., $\mathrm{CH}_{4}$ dynamics; Borges et al., 2015b) and aquatic ecology (e.g., phytoplankton development; Descy et al., 2016) between these two rivers. The hydrological cycle of the Congo River at Kisangani and Kinshasa is similar, with a bimodal distribution: maximum water peaks occur in December and May and minimum flow in August and March (Fig. 2). The center of the basin is covered by evergreen forest ( $\sim 50 \%$ of the total area) and is surrounded by savannah on the northern and southern rims of the catchment. The $\mathrm{Cu}-$ vette Centrale is located in the central part of the basin on both sides of the Equator and mainly consists of a vast permanently flooded forested area of $360 \times 10^{3} \mathrm{~km}^{2}$ (Bwangoy et al., 2010). The core of the Cuvette Centrale corresponds to the net increase in the wetland fraction along the Congo River as the mainstem connects with large tributaries flowing through the flooded forest (Fig. 1 and Supplement Fig. S1). The most important tributaries of the Congo in terms of discharge are the Oubangui $\left(4200 \mathrm{~m}^{3} \mathrm{~s}^{-1}\right)$ and the Sangha $\left(2220 \mathrm{~m}^{3} \mathrm{~s}^{-1}\right)$ on the northern side, the Kasai $\left(9000 \mathrm{~m}^{3} \mathrm{~s}^{-1}\right)$ 


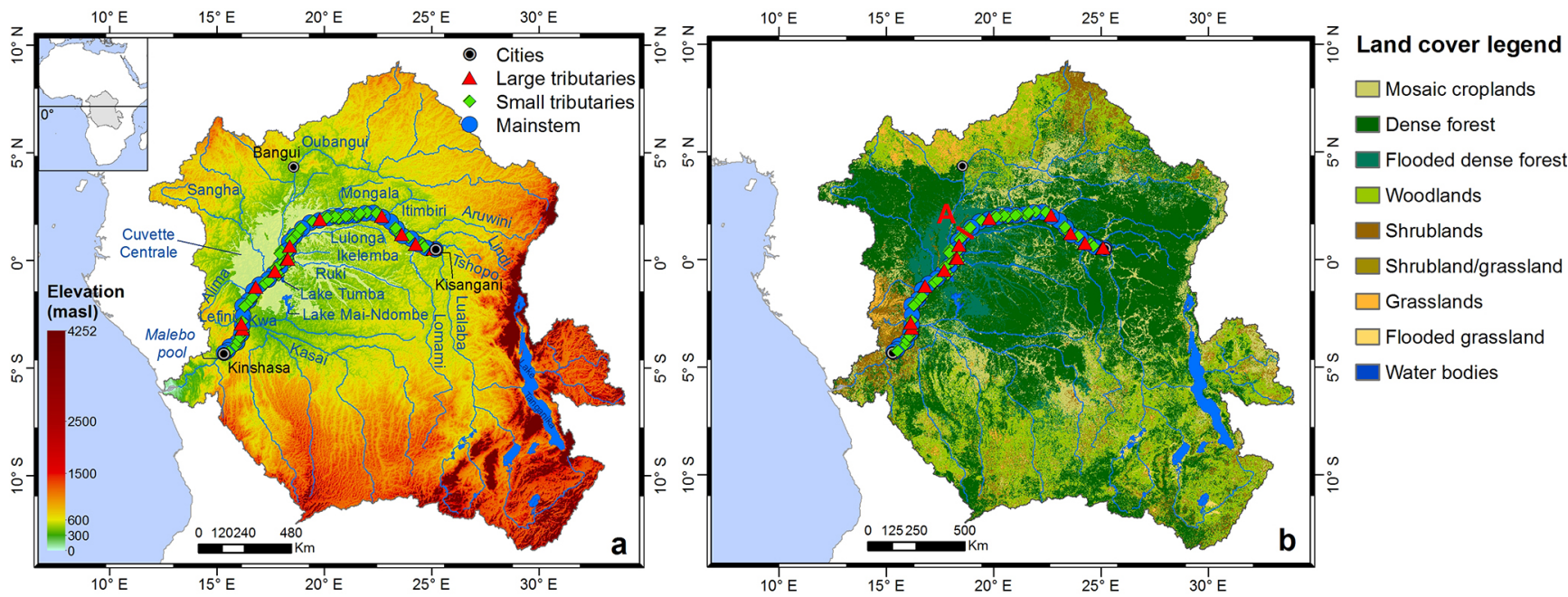

Figure 1. Maps of the Congo Basin. (a) The elevation (Lehner et al., 2008), the main hydrological network, the extent of the Cuvette Centrale (Lehner and Döll, 2004), and the distribution of sampling sites along the Kisangani-Kinshasa transect. (b) The dominant land cover (Bontemps et al., 2011). The red line "A" indicates the entrance of the Congo River within the core of the Cuvette Centrale (see text for details and Fig. S1).

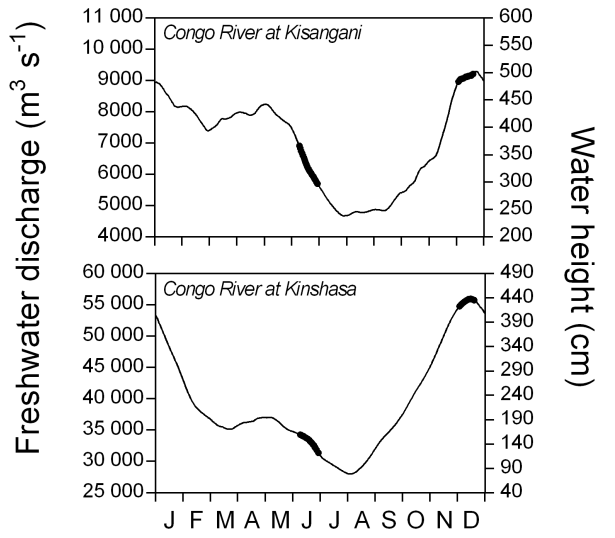

Figure 2. Average freshwater discharge of the Congo River, as well as corresponding water height at the gauging station at (a) Kisangani for the period 2013-2016 and (b) Kinshasa for the period 2003-2013. Timing of the two cruises is indicated by thicker lines.

on the southern side, and the Ruki $\left(3950 \mathrm{~m}^{3} \mathrm{~s}^{-1}\right)$ and the Lulonga $\left(2040 \mathrm{~m}^{3} \mathrm{~s}^{-1}\right)$ along the Equator (Bricquet, 1995; Coynel et al., 2005; Laraque et al., 2009).

\subsection{Field data collection}

Samples were collected during the yearly discharge maximum in December (3-19 December 2013; high waters (HW)) and during falling waters (FW) following the second discharge maximum occurring in March (10-30 June 2014) (Fig. 2). As the water level of the Congo River follows similar seasonal fluctuations at Kisangani and Kinshasa (Fig. 2), the timing of high and low waters was likely similar for the sites located along the mainstem. WRT between
Kisangani and Kinshasa has been roughly estimated to increase by about $\sim 5$ days during FW compared to HW (Descy et al., 2016) but is likely not uniform along the transect: because the main tributaries are all located downstream, the increase in WRT is probably more important upstream of the Oubangui. Water samples were collected in the Congo River itself as well as in small and large tributaries at the confluence (Table 1). Stations along the mainstem were located $\sim 50 \mathrm{~km}$ apart from Kisangani to Kinshasa. Major tributaries included the Tshopo, the Lindi, the Itimbiri, the Aruwimi, the Mongala, the Oubangui, the Sangha and the Lefini on the right bank of the Congo, and the Lomami, the Lulonga, the Ikelemba, the Ruki and the Kwa/Kasai on the left bank. The Lefini was sampled only during the first campaign (high waters).

Water sampling was performed from a $22 \mathrm{~m}$ boat on the mainstem and with a canoe in the tributaries. Approximately $2 \mathrm{~L}$ of water was collected $0.5 \mathrm{~m}$ below the surface, stored away from direct sunshine and filtered and conditioned typically within 15 min of sampling. Filtrations were performed successively on pre-combusted GF/F glass fiber filters $(0.7 \mu \mathrm{m}$ porosity), then on $0.2 \mu \mathrm{m}$ polyethersulfone syringe filters. Samples for the measurement of DOC concentrations and $\delta^{13} \mathrm{C}_{\mathrm{DOC}}$ signatures were stored in $40 \mathrm{~mL}$ glass vials with polytetrafluoroethylene (PTFE)-coated septa with $50 \mu \mathrm{L}$ of $\mathrm{H}_{3} \mathrm{PO}_{4}(85 \%)$. Samples for colored DOM (CDOM) and fluorescent DOM (FDOM) analyses were stored in $20 \mathrm{~mL}$ amber glass vials with PTFE-coated septa but without $\mathrm{H}_{3} \mathrm{PO}_{4}$ addition. Samples for CDOM and FDOM were stored just after filtration at $4{ }^{\circ} \mathrm{C}$ in a refrigerator on the boat until transportation back to Belgium, where they were also stored at $4{ }^{\circ} \mathrm{C}$ until analysis within 1 week of arrival. Potential stor- 
Table 1. Selected attributes (mean \pm standard deviation, min-max) of sampling sites during the field campaigns: oxygen saturation level $\left(\% \mathrm{O}_{2}\right), \mathrm{pH}$, Secchi depth, vertical light attenuation coefficient $\left(K_{\mathrm{d}}\right)$, total suspended matter (TSM) and chlorophyll $a($ Chl $a)$ concentrations (data from Descy et al., 2016).

\begin{tabular}{|c|c|c|c|c|c|c|c|}
\hline Period & $n$ & $\begin{array}{r}\% \mathrm{O}_{2} \\
(\%)\end{array}$ & $\mathrm{pH}$ & $\begin{array}{r}\text { Secchi } \\
(\mathrm{cm})\end{array}$ & $\begin{array}{r}K_{\mathrm{d}} \\
\left(\mathrm{m}^{-1}\right)\end{array}$ & $\begin{array}{r}\mathrm{TSM} \\
\left(\mathrm{mg} \mathrm{L}^{-1}\right)\end{array}$ & $\begin{array}{r}\text { Chl } a \\
\left(\mu \mathrm{g} \mathrm{L}^{-1}\right)\end{array}$ \\
\hline \multicolumn{8}{|c|}{ Maximum high waters } \\
\hline Mainstem & 35 & $\begin{array}{l}60.3 \pm 10.6 \\
(48.4-89.2)\end{array}$ & $\begin{array}{l}6.46 \pm 0.22 \\
(6.07-6.92)\end{array}$ & $\begin{array}{r}54.6 \pm 15.6 \\
(25-80)\end{array}$ & $\begin{array}{l}1.5 \pm 0.4 \\
(1.0-2.8)\end{array}$ & $\begin{array}{l}29.4 \pm 21.9 \\
(14.0-99.8)\end{array}$ & $\begin{array}{l}0.84 \pm 0.42 \\
(0.10-1.76)\end{array}$ \\
\hline Major tributaries & 13 & $\begin{array}{l}54.3 \pm 33.3 \\
(8.6-111.3)\end{array}$ & $\begin{array}{l}5.67 \pm 1.09 \\
(3.91-6.87)\end{array}$ & $\begin{array}{r}79.5 \pm 60.7 \\
(25-250)\end{array}$ & $\begin{array}{l}1.5 \pm 0.6 \\
(0.4-2.5)\end{array}$ & $\begin{array}{l}12.5 \pm 13.3 \\
(0.74-44.4)\end{array}$ & $\begin{array}{l}0.54 \pm 1.02 \\
(0.01-3.57)\end{array}$ \\
\hline Minor tributaries & 26 & $\begin{array}{r}27.9 \pm 30.2 \\
(4.2-99.8)\end{array}$ & $\begin{array}{l}5.33 \pm 0.75 \\
(3.91-6.17)\end{array}$ & $\begin{array}{r}86.2 \pm 29.7 \\
(15-140)\end{array}$ & $\begin{array}{l}1.5 \pm 0.5 \\
(0.9-2.8)\end{array}$ & $\begin{array}{l}7.7 \pm 13.4 \\
(1.7-71.4)\end{array}$ & $\begin{array}{r}0.35 \pm 0.42 \\
(0-1.85)\end{array}$ \\
\hline \multicolumn{8}{|c|}{ Falling waters after second peak water discharge } \\
\hline Mainstem & 34 & $\begin{array}{r}84.8 \pm 7.4 \\
(54.2-93.4)\end{array}$ & $\begin{array}{l}6.82 \pm 0.32 \\
(6.08-7.38)\end{array}$ & $\begin{array}{r}46.8 \pm 5.7 \\
(35-62)\end{array}$ & $\begin{array}{l}3.9 \pm 0.6 \\
(1.5-4.6)\end{array}$ & $\begin{array}{l}31.9 \pm 9.1 \\
(4.0-45.4)\end{array}$ & $\begin{array}{l}3.99 \pm 1.54 \\
(1.13-7.68)\end{array}$ \\
\hline Major tributaries & 12 & $\begin{array}{r}62.1 \pm 31.2 \\
(0.3-98.2)\end{array}$ & $\begin{array}{l}5.77 \pm 1.22 \\
(3.63-7.05)\end{array}$ & $\begin{array}{r}66.7 \pm 23.4 \\
(35-106)\end{array}$ & $\begin{array}{l}3.3 \pm 0.7 \\
(2.4-5.1)\end{array}$ & $\begin{array}{l}14.4 \pm 12.5 \\
(0.73-43.0)\end{array}$ & $\begin{array}{l}1.65 \pm 2.27 \\
(0.02-6.39)\end{array}$ \\
\hline Minor tributaries & 41 & $\begin{array}{l}37.8 \pm 35.6 \\
(0.3-103.0)\end{array}$ & $\begin{array}{r}4.56 \pm 0.77 \\
(3.6-6.1)\end{array}$ & $\begin{array}{r}80.7 \pm 42.2 \\
(38-205)\end{array}$ & $\begin{array}{l}3.3 \pm 0.9 \\
(1.5-5.2)\end{array}$ & $\begin{array}{r}6.1 \pm 6.5 \\
(0.5-34.8)\end{array}$ & $\begin{array}{l}0.55 \pm 0.99 \\
(0.01-5.12)\end{array}$ \\
\hline
\end{tabular}

age and degradation effects were assessed by analyzing a series of contrasting samples after 3 months (Fig. S2). The differences in optical proxies $\left(a_{350}, \mathrm{SUVA}_{254}\right.$ and $\left.S_{\mathrm{R}}\right)$ were less than $5 \%(n=22)$ and no significant changes were observed by comparing excitation-emission matrices (EEMs). Samples for major elements (including Fe) were stored in 20 mL scintillation vials and acidified with $50 \mu \mathrm{L}$ of $\mathrm{HNO}_{3} 65 \%$ prior to analysis.

Fe was measured by inductively coupled plasma spectrometry (Agilent $7700 \times$ ICP-MS). DOC and $\delta^{13} \mathrm{C}_{\text {DOC }}$ were analyzed with an Aurora1030 total organic carbon analyzer (OI Analytical) coupled to a Delta V Advantage isotope ratio mass spectrometer. Typical precision observed in duplicate samples was in $>95 \%$ cases $< \pm 5 \%$ for DOC and $\pm 0.2 \%$ o for $\delta^{13} \mathrm{C}_{\mathrm{DOC}}$. Quantification and calibration were performed with series of standards prepared in different concentrations, using both IAEA-C6 $\left(\delta^{13} \mathrm{C}=-10.4 \%\right)$ and in-house sucrose standards $\left(\delta^{13} \mathrm{C}=-26.9 \%\right)$. All data are reported in the $\delta$ notation relative to VPDB (Vienna Pee Dee Belemnite). Absorbance was recorded on a Perkin-Elmer UV-visible $650 \mathrm{~S}$ spectrophotometer using a $1 \mathrm{~cm}$ quartz cuvette. Absorbance spectra were measured between 200 and $700 \mathrm{~nm}$ in $1 \mathrm{~nm}$ increments, and instrument noise was assessed measuring ultrapure (Type 1) Milli-Q (Millipore) water as a blank. After subtracting the blank spectrum, the correction for scattering and index of refraction was performed by fitting the absorbance spectra to the data over the $200-700 \mathrm{~nm}$ range according to the following equation:

$A_{\lambda}=A_{0} e^{-S\left(\lambda-\lambda_{0}\right)}+K$

where $A_{\lambda}$ and $A_{0}$ are the absorbance measured at defined wavelength $\lambda$ and at reference wavelength $\lambda_{0}=375 \mathrm{~nm}$, re- spectively, $S$ is the spectral slope $\left(\mathrm{nm}^{-1}\right)$ that describes the approximate exponential decline in absorption with increasing wavelength, and $K$ is a background offset. The fit was not used for any purpose other than to provide an offset value $K$ that was then subtracted from the whole spectrum (Lambert et al., 2015). Fluorescence intensity was recorded on a Perkin-Elmer LS45 fluorescence spectrometer using a $1 \mathrm{~cm}$ quartz cuvette across excitation wavelengths of $220-450 \mathrm{~nm}$ (5 nm increments) and emission wavelengths of $230-600 \mathrm{~nm}$ $(0.5 \mathrm{~nm}$ increments) in order to build EEMs. If necessary, samples were diluted until $A_{254}<0.2 \mathrm{~m}^{-1}$ to avoid problematic inner filter effects (Ohno, 2002). Before each measurement session (i.e., each day), a Milli-Q water sample was also measured and subtracted from EEMs.

Water temperature, $\% \mathrm{O}_{2}$, and $\mathrm{pH}$ were measured in situ with portable field probes calibrated using standard protocols (YSI ProPlus probe). Pelagic respiration $(R)$ was determined from the decrease in $\mathrm{O}_{2}$ in $60 \mathrm{~mL}$ biological oxygen demand bottles over $\sim 24 \mathrm{~h}$ incubation periods. The bottles were kept in the dark and close to in situ temperature in a cool box filled with in situ water. The $\mathrm{O}_{2}$ decrease was determined from triplicate measurements at the start and the end of the incubation with an optical $\mathrm{O}_{2}$ probe (YSI ProODO). The respiratory quotient (RQ), defined as the molar ratio of $\mathrm{O}_{2}$ consumed to $\mathrm{CO}_{2}$ produced by respiration, allows the conversion of respiration measurements from $\mathrm{O}_{2}$ to $\mathrm{C}$ units. The RQ value is in theory equal to 1 for the oxidation of glucose but higher than 1 for more complex and reduced organic molecules, such as lipids and proteins (e.g., 1.3 in a temperate stream with a catchment dominated by pastures; Richardson et al., 2013), or lower than 1 for highly oxidized and oxygen-rich molecules (e.g., 0.8 in boreal lakes; Berggren et al., 2012). 
Given the range of RQ values, we adopted a $R Q$ value of 1.0. The vertical light attenuation coefficient, $K_{\mathrm{d}}\left(\mathrm{m}^{-1}\right)$, was calculated from simultaneous measurements of surface irradiance with a Li-Cor LI-190 quantum sensor and underwater photosynthetically active radiation (PAR) measurements with a submersible Li-Cor LI-193SA spherical quantum sensor. $K_{\mathrm{d}}$ was derived from the slope of the semi-logarithmic regression between relative quantum irradiance and depth. Transparency of the water column was measured using a $20 \mathrm{~cm}$ diameter Secchi disk.

\subsection{Characterization of DOM composition}

The specific ultraviolet absorbance $\left(\mathrm{SUVA}_{254}\right)$ was calculated as the UV absorbance at $\lambda=254 \mathrm{~nm}\left(A_{254}\right)$ normalized to the corresponding DOC concentration (Weishaar et al., 2003). The natural UV absorbance of $\mathrm{Fe}$ at $\lambda=254 \mathrm{~nm}$ was estimated based on measured Fe concentrations and was then subtracted from the UV absorbance measured. The corrected value of $A_{254}$ was then used to calculate $\mathrm{SUVA}_{254}$. The $\mathrm{SUVA}_{254}$ was used as an indicator of the aromaticity with higher values indicative of greater percent of aromaticity (Weishaar et al., 2003).

Napierian absorption coefficients were calculated according to

$a_{\lambda}=2.303 \times A_{\lambda} / L$,

where $a_{\lambda}$ is the absorption coefficient $\left(\mathrm{m}^{-1}\right)$ at wavelength $\lambda, A_{\lambda}$ the absorbance corrected at wavelength $\lambda$ and $L$ the path length of the optical cell in meters $(0.01 \mathrm{~m})$. CDOM was reported as the absorption coefficient at $350 \mathrm{~nm}\left(a_{350}\right)$. Spectral slopes for the intervals $275-295\left(S_{275-295}\right) \mathrm{nm}$ and 350 $400 \mathrm{~nm}\left(S_{350-400}\right)$ were determined from the linear regression of the log-transformed $a$ spectra vs. wavelength. The slope ratio $S_{\mathrm{R}}$ was then calculated as the ratio of $S_{275-295}$ to $S_{350-400} . S_{\mathrm{R}}$ is inversely related to the molecular weight (MW) distribution of DOM (Helms et al., 2008). The fluorescence index (FI) was calculated as the ratio of the emission intensities at 470 and $520 \mathrm{~nm}$ at an excitation wavelength of $370 \mathrm{~nm}$ (McKnight et al., 2001). A higher FI value (e.g., 1.8) indicates an aquatic microbial DOM source, while a lower value (e.g., 1.2) indicates a terrestrial source. Intermediate values indicate a mixed DOM source.

\subsection{PARAFAC modeling}

EEM preprocessing (including removing first and second Raman scattering, standardization to Raman units, absorbance corrections and inner filter effects) was performed prior to the PARAFAC modeling. The scans were standardized to Raman units (normalized to the integral of the Raman signal between 390 and $410 \mathrm{~nm}$ in emission at a fixed excitation of $350 \mathrm{~nm}$ ) with a Milli-Q water sample run the same day as the samples (Zepp et al., 2004). The PARAFAC model was built using MATLAB (MathWorks, Natick, MA, USA) and the drEEM toolbox version 1.0 (Murphy et al., 2013). Validation of the model was performed by split-half analysis and random initialization. The normalization step was applied to scale each EEM to its total signal, thus ensuring the model focused entirely on compositional rather than concentration gradients. Additional samples analyzed in the same manner and collected from the Kwa/Kasai River basin $(n=104)$, Lago Janauacá (a central Amazon floodplain lake, $n=17)$, the Niger River $(n=19)$ and the Okavango Delta $(n=17)$ were added to the dataset to increase the variability in DOM fluorescence signatures and help detect components that could have been present in insufficient quantity to be detected in our environment. The maximum fluorescence $F_{\text {Max }}$ values of each component for a particular sample provided by the model were summed to calculate the total fluorescence signal $F_{\text {Tot }}$ of the sample in Raman units. The relative abundance of any particular PARAFAC component $X$ was then calculated as $\% \mathrm{C}_{X}=F_{\mathrm{Max}}(X) / F_{\mathrm{Tot}}$.

The positions of maximum peaks established by the model were compared to the classical excitation-emission matrix nomenclature (Fellman et al., 2010; Coble et al., 2014) and with other reported PARAFAC models built in a large variety of freshwater ecosystems (Table 2). Additionally, each PARAFAC component was associated with a dominant molecular class based on recent studies aiming to correlate individual molecular formula with different PARAFAC components through Fourier transform ion cyclotron resonance mass spectrometry (FTICR-MS). Such studies have been carried out in Swedish lakes (Kellerman et al., 2015), boreal streams and rivers (Stubbins et al., 2014), and a subtropical wetland (Wagner et al., 2015). Although such a comparison has not been performed with our own samples, the relatively good consistency of associations between optical and molecular linkages observed in these contrasting environments suggests that PARAFAC components can track dominant DOM molecular composition similarly across different biomes in terms of DOM MW and enrichment in aliphatic or aromatic molecules (Wagner et al., 2015).

\subsection{Landscape analysis}

The total drainage area and the Strahler stream order (Strahler, 1957) were calculated at each station in the geographic information system (GIS) software ArcGis ${ }^{\circledR}$ (ESRI 2011, ArcGis Desktop 10.3.1), using the ArcHydro tools (v. 2.0) and the hydrological data and maps based on shuttle elevation derivatives at a 3 arcsec resolution (Lehner et al., 2008). The extents of wetland areas and flooded dense forest cover were extracted from the Global Lakes and Wetlands Database (Lehner and Döll, 2004) and from Global Land Cover 2009 database (Bontemps et al., 2011), respectively. 


\subsection{Statistical analysis}

Mann-Whitney $t$ tests were performed to investigate differences in DOM properties spatially (mainstem vs. tributaries) and temporally (HW vs. FW). A principal component analysis (PCA) was also performed to explore DOM evolution during its transport through the Congo fluvial network. The optical properties of DOM, including level of CDOM $\left(a_{350}\right)$, bulk composition $\left(\mathrm{SUVA}_{254}, S_{\mathrm{R}}, \mathrm{FI}\right)$ and the relative abundance of PARAFAC components, were used as the variables. Given the different units of these variables, data were scaled to zero mean and unit variance as recommended by Borcard et al. (2011). The PCA was performed using the prcomp function in R software.

\section{Results}

\subsection{DOC concentrations and DOM bulk composition}

DOC concentrations in the mainstem were higher during HW (5.4-13.9 $\mathrm{m} \mathrm{L}^{-1}$, average $8.2 \pm 2.6 \mathrm{mg} \mathrm{L}^{-1}$ ) compared to FW (4.2-9.8 $\mathrm{mg} \mathrm{L}^{-1}$, average $5.9 \pm 1.8 \mathrm{mg} \mathrm{L}^{-1}$ ) but showed similar longitudinal patterns during both hydrological periods (Fig. 3a, b): DOC increased slowly in the upper part of the transect $\left(0.0012 \mathrm{mg} \mathrm{DOC} \mathrm{km}^{-1}\right.$ at $\mathrm{HW}$ and $0.0002 \mathrm{mg} \mathrm{DOC} \mathrm{km}^{-1}$ at FW) and then faster as the Congo River evolved throughout the core of the Cuvette Centrale and mixed with the Kwa/Kasai River $\left(0.0091 \mathrm{mg}\right.$ DOC km${ }^{-1}$

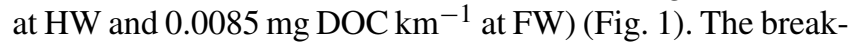
ing point in the DOC longitudinal increase in DOC concentrations was located around kilometer 700 during HW, and kilometer 500 during FW. DOC concentrations in tributaries were highly variable (from 1.8 to $67.8 \mathrm{mg} \mathrm{L}^{-1}$ ) and were found to be correlated with the extent of flooded forest (Fig. 4), resulting in highest concentrations in tributaries draining the Cuvette Centrale and lowest concentrations in those draining savannah areas upstream of Kinshasa (Fig. 1). Tributaries located downstream of the Cuvette Centrale were also characterized by lowest DOC concentrations during FW compared to HW, while no clear pattern was observed for those located upstream.

$\delta^{13} \mathrm{C}_{\mathrm{DOC}}$ signatures in the mainstem were lower during HW (from -30.6 to $-28.8 \%$, average $-29.4 \pm 0.3 \%$, $n=35$ ) compared to FW (from -29.3 to $-25.2 \%$, average $-27.5 \pm 0.9 \%$, $n=34) . \delta^{13} \mathrm{C}_{\mathrm{DOC}}$ during HW decreased about $0.7 \%$ from Kisangani to ca. kilometer 1200 , remained stable until ca. kilometer 600 and then increased slightly towards Kinshasa. During FW, $\delta^{13} \mathrm{C}_{\mathrm{DOC}}$ decreased markedly about 3\%o between Kisangani and ca. kilometer 1600 . Downstream, values were variable $(-27.2 \pm 0.6 \%$ o between kilometers 600 and 1600, $n=18$ ) and then showed $\sim 1 \%$ o drops at ca. kilometer 600 and ca. 200, coinciding with the confluence zones with the Oubangui and the Kwa/Kasai rivers, respectively. In tributaries, $\delta^{13} \mathrm{C}_{\mathrm{DOC}}$ values displayed

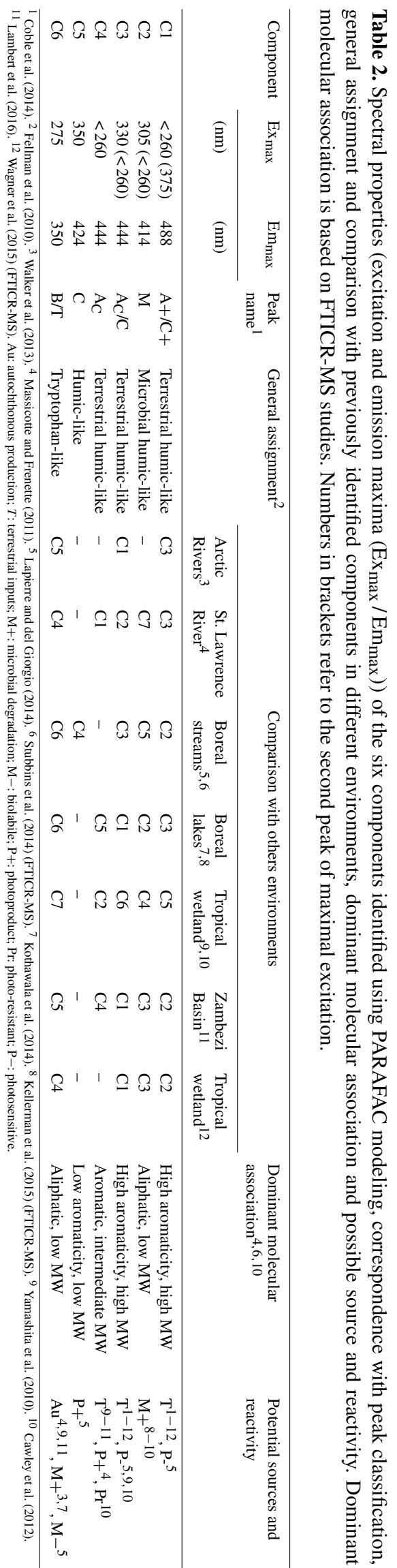

www.biogeosciences.net/13/5405/2016/ 


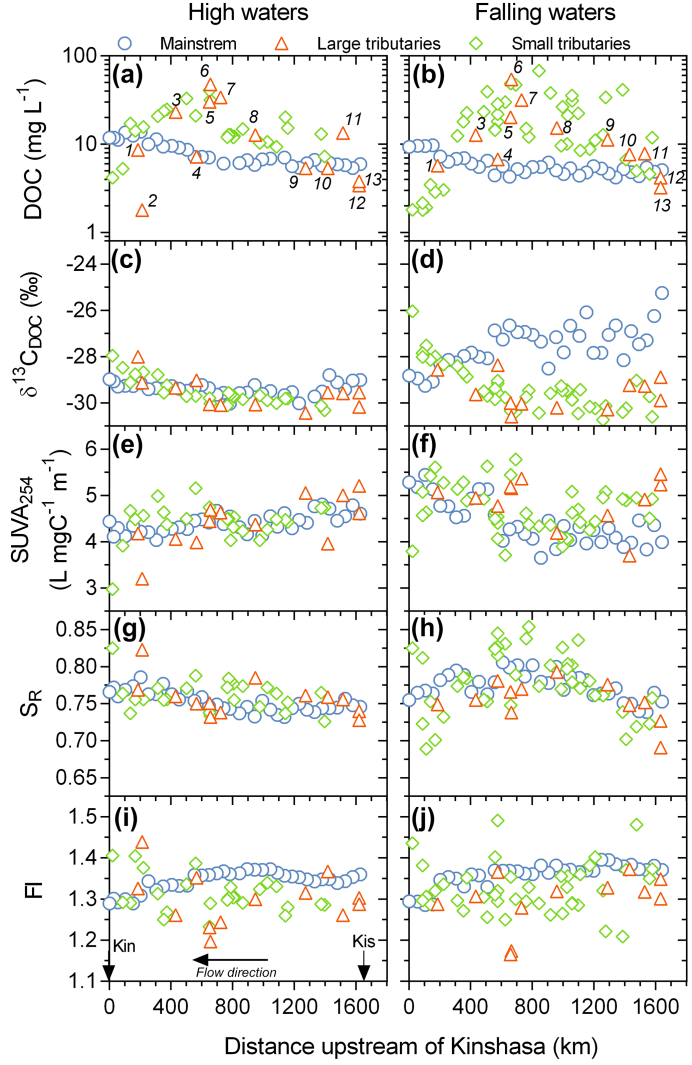

Figure 3. Longitudinal evolution of DOM properties in the mainstem, large and small tributaries along the Kisangani-Kinshasa transect during $\mathrm{HW}$ (left panels) and FW (right panels). From top to bottom, the panels represent DOC, $\delta^{13} \mathrm{C}_{\mathrm{DOC}}, \mathrm{SUVA}_{254}, S_{\mathrm{R}}$ and FI. Numbers refer to large tributaries: (1) the Kwa/Kasai, (2) the Lefini, (3) the Sangha, (4) the Oubangui, (5) the Ruki, (6) the Ikelemba, (7) the Lulonga, (8) the Mongala, (9) the Itimbiri, (10) the Aruwimi, (11) the Lomami, (12) the Lindi and (13) the Tshopo.

a similar pattern during the two hydrological periods with low and relatively stable values $(-29.7 \pm 0.5 \%, n=76)$ in streams and rivers draining dense forest areas and higher signatures in those flowing savannah areas $0-400 \mathrm{~km}$ upstream of Kinshasa $(-28.1 \pm 0.8, n=14)$. Stations of the mainstem located within or upstream of the Cuvette Centrale were characterized by higher $\delta^{13} \mathrm{C}_{\mathrm{DOC}}$ values than those measured in tributaries collected along the same transect, during both HW $(p<0.004)$ and FW $(p<0.0001)$. Downstream of the Cuvette Centrale, stations of the mainstem had lower $\delta^{13} \mathrm{C}_{\mathrm{DOC}}$ signatures than those measured in tributaries $(p<0.0001$, all periods).

$\mathrm{SUVA}_{254}$ and $S_{\mathrm{R}}$ during both periods varied mainly between 4.0 and $5.2 \mathrm{~L} \mathrm{mg} \mathrm{C}^{-1} \mathrm{~m}^{-1}$ and between 0.734 and 0.802 among all stations, respectively (10-90\% percentiles, $n=160$ ), indicating that DOM in the Congo Basin was dominated by aromatic compounds of high MW during both periods (Fig. 3e-h). SUVA 254 generally decreased from Kisangani to Kinshasa in the mainstem during HW, with a slight increase between kilometers 500 and 800 upstream of Kinshasa, while $S_{\mathrm{R}}$ exhibited stable values from Kisangani and then started to increase towards Kinshasa at kilometer 700 . Compared to $\mathrm{HW}, \mathrm{SUVA}_{254}$ during $\mathrm{FW}$ was relatively stable and lowest from Kisangani to kilometer 500 but higher between kilometers 0 and 500 as SUVA $_{254}$ increased markedly in this section $(p<0.0001) . S_{\mathrm{R}}$ exhibited a hump-shaped pattern during $\mathrm{FW}$, with increasing values from Kisangani to kilometer 500 and decreasing value between kilometers 0 and 500. A slight decrease in $\mathrm{SUVA}_{254}$ $(p=0.0043)$ associated with an increase in $S_{\mathrm{R}}(p=0.047)$ was also observed between kilometers 200 and 400. Generally, $\mathrm{SUVA}_{254}$ in tributaries were slightly higher at FW than at HW $(p=0.035)$, similar to the mainstem in HW but higher in FW $(p=0.0113)$. FI in the mainstem gradually decreased from Kisangani to Kinshasa during both hydrological periods, with higher values during FW than at HW $(p=0.0006)$, and were higher than in tributaries $(p<0.0001)$. No distinct seasonal variation was apparent in tributaries.

\subsection{PARAFAC results}

Six PARAFAC components were determined to adequately model our dataset (Table 2, Fig. S3). Components C1, C3, $\mathrm{C} 4$, and $\mathrm{C} 5$ are all classified as "humic-like" but differ in terms of sources, molecular association and reactivity (Table 2). $\mathrm{C} 1$ and $\mathrm{C} 3$ are commonly reported in freshwaters and are associated with a group of high MW and aromatic molecules of terrestrial origin (e.g., Wagner et al., 2015). Both are susceptible to photodegradation (Lapierre and del Giorgio, 2014). C4 is associated with terrigenous molecules of lower aromaticity and MW relative to $\mathrm{C} 1$ and $\mathrm{C} 3$ (Kellerman et al., 2015). C4 commonly originates from terrestrial inputs (Stedmon and Markager, 2005; Yamashita et al., 2010; Lambert et al., 2016) and has been shown to be resistant to photodegradation (Massicotte and Frenette, 2010; Ishii and Boyer, 2012). Among the humic-like compounds, C5 is associated with molecules characterized by lowest aromaticity and MW produced during the photodegradation of terrestrial DOM (Lapierre and del Giorgio, 2014; Stubbins et al., 2014). C2 and C6 are classified as microbial humic-like and tryptophan-like components, respectively (Fellman et al., 2010). In contrast to the other components, $C 2$ and $C 6$ are associated with low MW DOM fractions enriched in aliphatic molecules biologically produced within aquatic ecosystems (Kellerman et al., 2015; Wagner et al., 2015). Both C2 and C6 can be assigned to a fraction of DOM produced during the microbial degradation of terrestrial DOM within freshwaters (Stedmon et al., 2003; Walker et al., 2013), although autochthonous primary production represents another potential source for C6 (Yamashita et al., 2010).

The relative contribution of $\mathrm{C} 1$ and $\mathrm{C} 3$ showed similar patterns along the mainstem during both periods (Fig. 5). \% 1 and $\% \mathrm{C} 3$ during $\mathrm{HW}$ presented a slight downstream decrease 


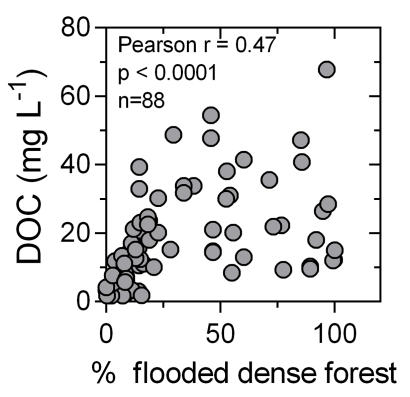

Figure 4. Relationships between DOC concentrations in tributaries and the extent of flooded dense forest.

followed by an increase with minimal contribution recorded around kilometer $1100 . \% \mathrm{C} 1$ and $\% \mathrm{C} 3$ were lowest during FW ( $p=0.017$ and $p<0.0001$, respectively), with low variability upstream of kilometer 500 and highest contribution downstream. \%C4 displayed a general increase along the transect at HW especially marked between Kisangani and ca. kilometer 1100 and between kilometers 600 and 150. During $\mathrm{FW}$, the longitudinal evolution of $\% \mathrm{C} 4$ showed an opposite pattern to those of $\% \mathrm{C} 1$ and $\% \mathrm{C} 3$, with a higher contribution than during HW $(p>0.0001)$. Overall, \% C5 was higher during FW than during HW $(p<0.0001)$ and exhibited longitudinal patterns opposite to those of \% 3 during both periods. $\% \mathrm{C} 2$ was relatively stable along the mainstem during both periods, with higher contribution during FW compared to HW ( $p=0.0076)$. C6 exhibited the lowest contribution to FDOM signal and \%C6 tended to be lower during FW compared to HW. Longitudinal evolution of C6 was characterized by a strong drop along the mainstem, occurring around kilometer 800 at $\mathrm{HW}$ and kilometer 500 at FW.

Overall, tributaries were characterized by higher $\% \mathrm{C} 3$ but lower $\% \mathrm{C} 2$ and $\% \mathrm{C} 6$ relative to the mainstem $(p<0.0001)$. $\% \mathrm{C} 4$ and $\% \mathrm{C} 1$ were higher $(p=0.0007)$ and lower ( $p=0.017)$, respectively, in tributaries than in the mainstem during HW, and no difference was observed at FW. No difference was observed for \% 55 between tributaries and the mainstem for both periods. The seasonal variability within tributaries was characterized by higher contribution of $\mathrm{C} 4$ $(p=0.025)$ and C5 $(p<0.0001)$ and lower contribution of $\mathrm{C} 3(p=0.0015)$ and C6 $(p=0.003)$ during FW compared to HW.

\subsection{PCA results}

The first two principal components (PC) accounted for $57 \%$ of the total variance (Fig. 6). The first PC (PC1) showed a transition from terrestrial aromatic DOM $\left(\% \mathrm{C} 3, \mathrm{SUVA}_{254}\right.$, DOC, $a_{350}$, positive loadings) to aliphatic DOM ( $\% \mathrm{C} 2$, \%C6, FI, negative loadings). Along the second PC (PC2), PARAFAC components are distributed with $\mathrm{C} 1$ and $\mathrm{C} 3$ as negative loadings and $\mathrm{C} 4$ and $\mathrm{C} 5$ as positive loadings. $\mathrm{C} 1$ and $\mathrm{C} 3$ have been identified as photosensitive (Yamashita et al.,

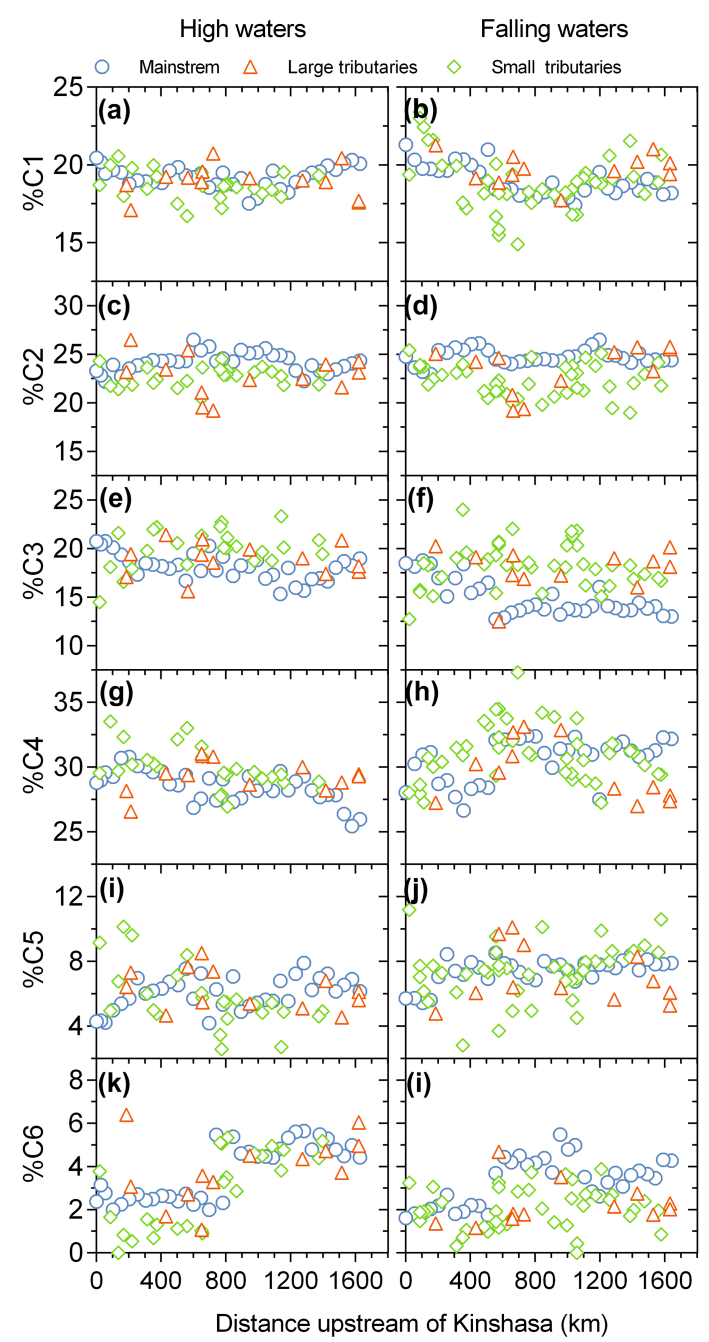

Figure 5. Longitudinal evolution of the relative contribution of PARAFAC component in the mainstem and large and small tributaries along the Kisangani-Kinshasa transect during HW (left panels) and FW (right panels).

2010; Lapierre and del Giorgio, 2014), while C4 and C5 are considered photo-resistant (Massicotte and Frenette, 2010; Ishii and Boyer, 2012) and produced by photodegradation (Lapierre and del Giorgio, 2014), respectively. Therefore, PC2 can be interpreted as being indicative of photodegradation (Cawley et al., 2012). The distribution of sampling stations for a given Strahler order was highly heterogeneous (Fig. 6a). However, a global pattern emerges along PC1 with stations collected in the mainstem showing mainly negative scores (Fig. 6b). Furthermore, stations of the mainstem collected during HW had negative scores along PC2 but positive scores during FW. Overall, stations collected during HW had mainly negative scores along PC2, while those sampled at FW showed large variability along PC2. 

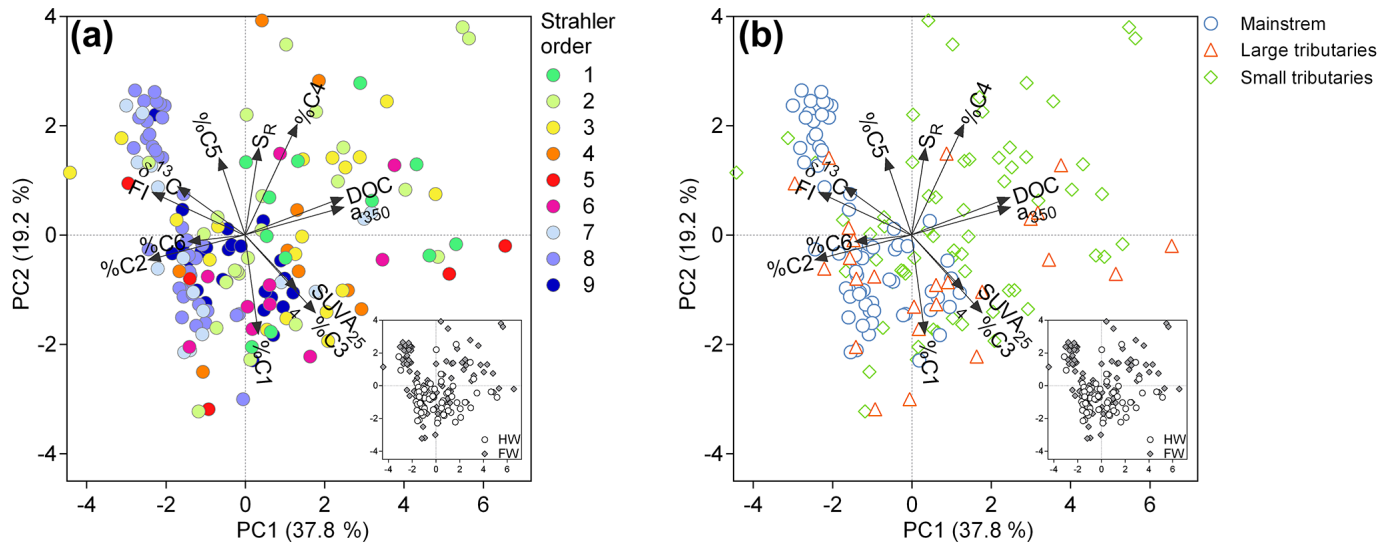

Figure 6. Graphical representation of PCA results, including a loadings plot for the input variables and a scores plot for stations based on (a) their Strahler stream order or (b) sampling location. PCA results based on the hydrological period is included in each plot.

\section{Discussion}

\subsection{Longitudinal evolution of DOM}

From Kisangani to Kinshasa the Congo River continually receives DOM inputs from tributaries flowing through the $\mathrm{Cu}$ vette Centrale (Fig. 4), resulting in a net longitudinal increase in DOC concentrations during both periods. However, the longitudinal evolution in DOM content and composition differed between the two campaigns due to the combination of several factors.

\subsubsection{Seasonal changes in DOM sources mobilized in the upper basin}

The large variation in $\delta^{13} \mathrm{C}_{\mathrm{DOC}}$ values in the mainstem at Kisangani between HW $(-29.0 \%)$ and FW $(-25.2 \%$ ) can be related to a shift in the source of DOM mobilized in the upper part of the basin due to differences in water routing during the hydrograph. Thus, decreasing $\delta^{13} \mathrm{C}_{\mathrm{DOC}}$ signatures that occurred during high-flow periods have been attributed to the mobilization of fresh DOM from superficial soil horizons in a wide variety of catchments (Neff et al., 2006; Sanderman et al., 2009; Lambert et al., 2011; Bouillon et al., 2012). Higher $\delta^{13} C_{D O C}$ values during low-flow periods reflect the deepening of water flow paths and the subsequent mobilization of more degraded DOM from deeper soil horizons. This seasonal change in DOM composition at the start of the Kisangani-Kinshasa transect is further supported by 0ongoing high-frequency sampling carried out at Kisangani (own unpublished data).

\subsubsection{Reduced lateral exchanges between the Congo River and the flooded forest during falling waters}

The decreasing but higher $\delta^{13} \mathrm{C}_{\mathrm{DOC}}$ signatures in the mainstem compared to tributaries during $\mathrm{FW}$ indicate a reduced lateral mixing between the central water masses of the Congo
River and DOM-rich waters from tributaries. Although we cannot rule out that lateral exchanges are likely driven by water level fluctuations in the Congo River, our data suggest that photodegradation of terrestrial DOM contributes to limit the downstream DOC enrichment during FW. Photodegradation is known to preferentially act on the colored, photosensitive molecules associated with high MW and aromaticity (Helms et al., 2008; Spencer et al., 2009; Lapierre and del Giorgio, 2014) and is expected to be highly efficient in aquatic ecosystems rich in light-absorbing CDOM such as the Congo River (Cawley et al., 2012; Cory et al., 2014). A stronger effect of DOM photodegradation in the mainstem during FW is supported by three lines of evidence in our data. First, $\mathrm{C} 1$ and C3 - both associated with highly aromatic molecules of high MW (Table 2) - were lower during FW compared to HW, and this decrease occurred along with a decrease in DOM aromaticity (lower $\mathrm{SUVA}_{254}$ ) and increase in average MW (higher $S_{\mathrm{R}}$ ) (Figs. 3 and 5). Second, the more drastic decrease in \% $\%$ is consistent with the well-documented high photosensitivity of this component relative to other terrestrial humic-like components (Yamashita et al., 2010; Cawley et al., 2012; Lapierre and del Giorgio, 2014). Finally, the PCA clearly separates stations collected in the mainstem between HW (negative scores) and FW (positive scores) along PC2, which shows that photodegradation is an important driver of DOM composition in the Congo Basin.

A stronger degree of DOM photodegradation during FW implies a higher exposure of CDOM to solar irradiation, either spatially (i.e., in the water column) or temporally. The higher coefficient of light attenuation in the water column $\left(K_{\mathrm{d}}\right)$ and lower Secchi depths during FW (Table 1) indicate that the penetration of sunlight in the water column was reduced compared to HW. This was likely due to the greater total suspended matter (TSM) concentrations (Table 1) and phytoplanktonic development (Descy et al., 2016), although CDOM likely remained the main driver of light penetration. Thus, the degree of DOM photodegradation appears to be 
mainly driven by changes in WRT that has been estimated to increase about $\sim 5$ days in FW compared to HW (Descy et al., 2016). Although sunlight depth penetration was low and the variation in the WRT relatively small, rates of photodegradation can be elevated in CDOM-rich ecosystems (Cory et al., 2015), and this process can substantially alter terrestrial DOM over a short timescale (e.g., $\sim 12 \mathrm{~h}$ of sunlight alteration according to Cory et al., 2015). Further research is needed in order to quantify photodegradation rate and the relative importance of this process on $\mathrm{C}$ cycling in the Congo Basin, but this was beyond the scope of the present study.

\subsubsection{Role of large tributaries and channel width in controlling the longitudinal evolution of DOM from Kisangani to Kinshasa}

DOM enrichment was more pronounced within the core of the Cuvette Centrale (Fig. 2), which corresponds to the region where the major tributaries in terms of discharge (i.e., the Lulonga, the Ruki, the Sangha, the Oubangui and the $\mathrm{Kwa} / \mathrm{Kasai}$ rivers) connect the mainstem. These tributaries are also very rich in terrestrial DOM from the large flooded forest (Coynel et al., 2005; Laraque et al., 2009) (Figs. 1 and $\mathrm{S} 1)$. DOC concentrations increased faster immediately as the Congo enters this central part of the Cuvette Centrale during $\mathrm{HW}$, reflecting the strong lateral mixing between water masses. However, the net rise in DOC concentrations during FW was found to occur first at $\sim 70 \mathrm{~km}$ downstream of the confluence zone with the Oubangui River, coinciding with a strong reduction of the channel width (Fig. S4). The $\sim 1 \%$ o drop in $\delta^{13} \mathrm{C}_{\text {DOC }}$ associated with changes in DOM composition (especially increase in $\mathrm{SUVA}_{254}$ and \%C3) at this station indicates that the reduction of the channel width favors the lateral mixing between the mainstem and waters from the Cuvette Centrale that travel along the river ridge lined by dense forest without being significantly impacted by photodegradation (Fig. S5). In fact, a "complete" lateral mixing with waters from the Cuvette Centrale occurs after the confluence zone with the Kwa/Kasai River (based on cross channel transects of conductivity and $\mathrm{pH}$, not shown). In this part of the river, the high discharge of the Kwa/Kasai combined with a narrow mainstem channel devoid of sandbars and islands (Runge et al., 2008) forces lateral mixing. This is supported by the fact that $\delta^{13} \mathrm{C}_{\mathrm{DOC}}$ signatures of the Congo mainstem became typical of black waters only after connecting with the Kwa/Kasai during FW, and could also explain why the DOC increase is greater at this point, while DOC is typically higher in tributaries located more upstream (e.g., the Ruki River).

Large tributaries also controlled the general evolution of DOM composition from Kisangani to Kinshasa. DOM aromaticity $\left(\mathrm{SUVA}_{254}\right)$ decreased slightly along the transect during $\mathrm{HW}$ (from $\sim 4.6$ to $4.2 \mathrm{mg} \mathrm{C} \mathrm{L}^{-1} \mathrm{~m}^{-1}$ from Kisangani to Kinshasa), but increased significantly during FW (from $\sim 4.0$ to $5.3 \mathrm{mg} \mathrm{C} \mathrm{L}^{-1} \mathrm{~m}^{-1}$ from Kisangani to Kinshasa) due to an increase in DOM aromaticity in large tributaries flowing through or connected to the Cuvette Centrale.

\subsection{DOM transformation during its downstream transport}

Strahler stream order was used as an organizing concept for the individual characterization of stream reaches within the network (Strahler, 1957; Poole, 2010), and in order to investigate DOM composition across a gradient of streams and rivers. Although DOM in the Congo Basin is dominated by terrestrial inputs of aromatic DOM, the loadings plot along $\mathrm{PC} 1$ indicates a transition in the dominant DOM composition from aromatic $\left(\% \mathrm{C} 3, \mathrm{SUVA}_{254}\right)$ to aliphatic $(\% \mathrm{C} 2, \% \mathrm{C} 6, \mathrm{FI})$ compounds (Fig. 6). It is noteworthy that similar gradients have recently been reported in Swedish lakes (Kellerman et al., 2015) and US rivers networks (Creed et al., 2015), suggesting that the large-scale governing processes controlling DOM in freshwater are similar across biomes. However, the underlying mechanisms remain to be elucidated. Thus, the gain in aliphatic DOM has been attributed to the increasing influence of autochthonous sources (Creed et al., 2015) or to the degradation of terrestrial DOM (Kellerman et al., 2015), while external factors (i.e., not related to DOM composition) have been suggested to have little influence on this pattern (Kellerman et al., 2015). Our study supports the hypothesis that the degradation of terrestrial DOM is the main driver of DOM transformation in aquatic systems, but it also highlights the role of landscape morphology and environmental conditions in influencing the transition from an aromatic- to aliphatic-dominant composition.

\subsubsection{Losses of aromatic DOM through photodegradation and biological activity as a producer of aliphatic DOM}

The role of photodegradation in removing the aromatic fraction of DOM in the Congo Basin, strongly suggested by the PCA as well as by the changes in DOM composition along the mainstem between $\mathrm{HW}$ and FW, is also supported by patterns in $\mathrm{C} 5$. Indeed, \% $\mathrm{C} 5$ was inversely related to \% $\mathrm{C} 3$ (Fig. 7a), suggesting that C5 tracks molecules directly produced during the photodegradation of terrestrial aromatic molecules as previously demonstrated in boreal freshwaters (Lapierre and del Giorgio, 2014). In addition, \%C5 was inversely related with measurements of pelagic community respiration $(R)$ performed concurrently with DOM sampling (Borges et al., 2015a) and attributed to bacterial respiration since phytoplankton biomass is generally low (Descy et al., 2016) (Fig. 7b). Given that C5 is associated with molecules of low MW and aromaticity (Stubbins et al., 2014), this observation is consistent with experimental results showing that the aromatic and high MW fraction of terrestrial DOM can be photochemically converted into more labile substances 

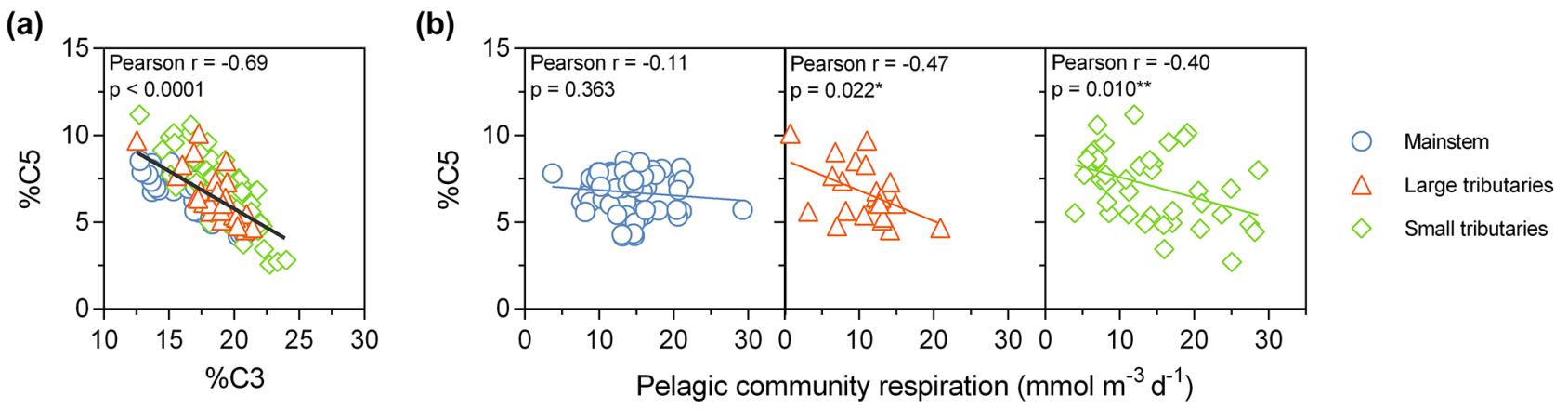

Figure 7. (a) Relationship between $\% \mathrm{C} 5$ and $\% \mathrm{C} 3$ and (b) relationships between $\% \mathrm{C} 5$ and pelagic community respiration $(R)$ in the Congo Basin.

of lower MW that in turn can support the aquatic bacterial metabolism (Bano et al., 1998; Tranvik and Bertilsson, 2001; Remington et al., 2011; Cory et al., 2014). The lack of correlation between \% 5 and $R$ in the mainstem likely indicates an additional source of labile DOM. The higher concentrations of chlorophyll $a$ in the mainstem compared to tributaries (Table 1) suggest that this source could be phytoplanktonic exudates that have been shown to be very labile and rapidly assimilated by bacteria (Baines and Pace, 1991; Morana et al., 2014).

The dual role of microorganisms as consumers of terrigenous aromatic DOM and producers of novel compounds has recently been emphasized (Guillemette and del Giorgio, 2012; Ward et al., 2013; Fasching et al., 2014) and could explain the gain in aliphatic DOM in the Congo River. Components $\mathrm{C} 2$ and C6 - associated with aliphatic molecules (Table 2) - exhibited systematically higher contributions in the mainstem compared to tributaries, implying a permanent internal production. However, none of these components were correlated to chlorophyll $a$ concentrations (data not shown), suggesting that the phytoplankton primary production in the Congo Basin was not controlling their distribution. On the other hand, several studies carried out in a wide variety of aquatic ecosystems have attributed the origin of components like $\mathrm{C} 2$ and $\mathrm{C} 6$ to the biological degradation of terrestrial DOM within the aquatic ecosystems (Stedmon et al., 2003; Yamashita et al., 2010; Walker et al., 2013; Fasching et al., 2014; Kellerman et al., 2015). Therefore, microbial reworking of terrestrial DOM during its transport could lead to the production of these components, an assumption supported by higher FI values in the mainstem inferring greater inputs of microbially derived DOM relative to tributaries (McKnight et al., 2001).

Our results contrast with previous investigations based on lignin biomarkers suggesting that DOM transformation in the Congo Basin is mainly driven by dynamic exchanges with the particulate organic carbon (POC) pool via sorption or leaching processes (Spencer et al., 2012; Mann et al., 2014). The $\delta^{13} \mathrm{C}$ signatures of POC collected during our field campaigns spanned a much wider range but were poorly correlated with $\delta^{13} \mathrm{C}_{\mathrm{DOC}}\left(R^{2}=0.20, p<0.0001 ; n=158\right.$, data not shown), suggesting limited exchange between these pools. However, our results are in line with previous field studies showing that downstream changes in DOM composition can be largely controlled by photodegradation (Massicotte and Frenette, 2011; Cawley et al., 2012).

\subsubsection{Role of external drivers on the transition from aromatic towards aliphatic}

The distribution of data in the PCA (Fig. 6) shows that (1) DOM in the mainstem is enriched in the aliphatic fraction compared to its tributaries and (2) the distribution of tributaries for a given Strahler order is strongly heterogeneous. This highlights the combined effects of landscape morphology and water chemistry that can influence the downstream transformation of DOM independently of the size of the streams/rivers. Thus, land cover - here mostly forest and savannah - has a strong influence on the composition of DOM released in aquatic ecosystems (Mann et al., 2014; Lambert et al., 2015), and DOM photodegradation is likely more pronounced in catchments with large open areas as suggested by the lower \% 3 in savannah-dominated catchments compared to forest-dominated catchments (Fig. S6). Also, a strong connectivity with terrestrial sources can maintain a greater aromatic character to DOM independently of the size of the rivers. This typically refers to the well-known role of wetland areas in delivering large quantities of aromatic DOM in inland waters (Battin et al., 1998; Hanley et al., 2013; Lambert et al., 2016) and thus obscuring variations in DOM occurring upstream. A multi-year monitoring illustrates, for example, that DOM in the Oubangui River at Bangui (i.e., upstream of the Cuvette Centrale, Fig. 1) experiences significant changes in composition between rising waters (June; DOM has few aromatic structures) and high waters (December; DOM is highly aromatic; Bouillon et al., 2014), while our data report highly aromatic DOM during both periods as the river becomes enriched in organic material from the flooded forest (Laraque et al., 2009). Finally, the positive correlations be- 


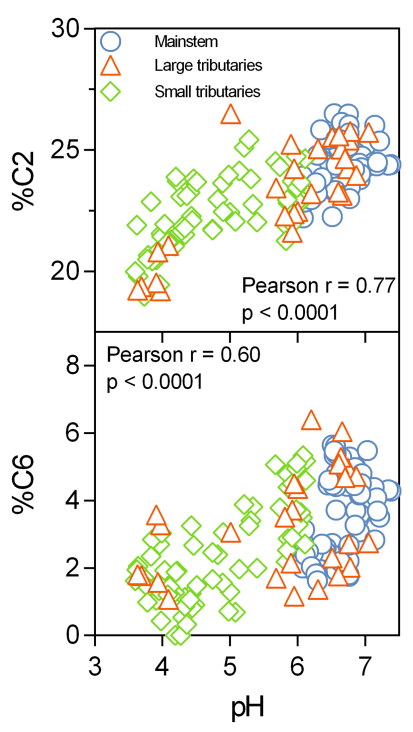

Figure 8. Relationship between the relative contribution of aliphatic components ( $\mathrm{C} 2$ and $\mathrm{C} 6$ ) and $\mathrm{pH}$ of stream waters in the Congo Basin.

tween \% 2 and $\mathrm{pH}$ and between \% 6 and $\mathrm{pH}$ (Fig. 8) advocate for a limited degree of bacterial degradation of DOM in very acidic environments as previously suggested by Borges et al. (2015a) based on the $\mathrm{CO}_{2}$ and DOC relationship in the Congo Basin. Such streams and rivers typically correspond to the DOM-rich "black waters" originating from the Cuvette Centrale, with pH between 3.6 and 5.9 and an average of 4.4 (Fig. S7).

\subsection{The chemostat hypothesis and the pulse-shunt concept}

The chemostat hypothesis suggests a decrease in DOC concentrations and a convergence in DOM composition towards lower aromaticity with increasing stream order due to the increasing influence of in-stream processes that overwhelm terrestrial inputs from headwater catchments (Creed et al., 2015). The shift from a predominantly terrestrial influence to biogeochemical processing - assessed by the variation of $\mathrm{SUVA}_{254}$ as a function of stream order - has been estimated to occur in third- or fourth-order streams in river networks across the United States (Creed et al., 2015). A net decrease in $\mathrm{SUVA}_{254}$ associated with a decrease with DOC concentrations was only found to occur from sixth- to eighth-order streams in our study (Fig. 9), reflecting the influence of the Cuvette Centrale (i.e., strong connectivity with the flooded dense forest, acidic waters) on the DOM biogeochemistry in the Congo Basin. Although the seasonal variations of water level are modest in the Congo and that the Cuvette Centrale does not flush as floodplain lakes in the Amazon (e.g., Moreira-Turcq et al., 2003), the flooded forest is drained by several large rivers (Ruki, Sangha) that bring large amounts

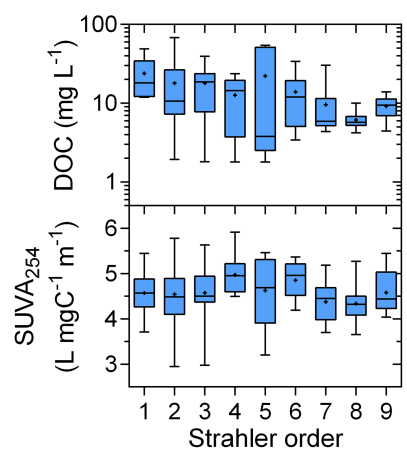

Figure 9. DOC concentrations and DOM aromaticity $\left(\mathrm{SUVA}_{254}\right)$ across a gradient of streams and rivers in the Congo Basin as a function of stream order. The box spans the interquartile range (25th75th percentiles), whiskers correspond to min-max values, and the horizontal bar and cross correspond to the median and average, respectively.

of water and DOM to the mainstem (the Ruki is the second tributary after the Kasai). This falls in line with the "flood pulse concept" of Junk et al. (1989) that highlights the critical importance of the river-floodplain connectivity in lowland tropical rivers (Battin, 1998; Zurbrügg et al., 2013; Lambert et al., 2016), while the chemostat hypothesis builds on the river continuum concept (Vannote et al., 1980) that is typically applicable to rivers at temperate latitudes and devoid of large wetlands. Patterns of other data acquired during the same cruises, such as $\mathrm{CO}_{2}$ and $\mathrm{CH}_{4}$, also showed the influence of inputs of these quantities from the Cuvette Centrale (Borges et al., 2015a). Also, an increase in DOM content and aromaticity was found to occur in ninth-order streams, reflecting the fact that DOM-rich waters from the Cuvette Centrale can travel along the ridge of the Congo River without completely mixing with the central water masses of the mainstem (Fig. S5).

Our study also supports the "pulse-shunt" conceptual model that states that the removal of terrestrial DOM in fluvial networks is a function of the hydrological regime of the basin (Raymond et al., 2016). It should be noted that the seasonal variation in water discharge is relatively low in the Congo Basin compared to other large rivers, yet apparently sufficient to significantly impact the degree of DOM photodegradation between FW and HW. The switch between active and passive pipes is likely to be more pronounced in large drainage basins in the Northern and Southern Hemisphere with more contrasting hydrological regimes, as recently shown in the adjacent Zambezi Basin (Lambert et al., 2016). Our results also suggest that the photodegradation pathway is more sensitive to changes in WRT compared to the biological pathway, but this hypothesis needs to be verified in other environments and by additional incubation experiments. 


\section{Data availability}

The digital elevation model HydroSHEDS (Lehner et al., 2008) is available at http://hydrosheds.cr.usgs.gov/index. php. The Global Lakes and Wetlands database (Lehner and Döll, 2004) is available at http://www.worldwildlife. org/pages/global-lakes-and-wetlands-database. The Global Land Cover 2009 database is available at http://landcover. usgs.gov/landcoverdata.php. The dataset is available upon request from A. V. Borges.

\section{The Supplement related to this article is available online at doi:10.5194/bg-13-5405-2016-supplement.}

Author contributions. Alberto V. Borges, François Darchambeau, Steven Bouillon designed the study; Alberto V. Borges and François Darchambeau collected the field data; Steven Bouillon and Thibault Lambert performed sample analysis; Thibault Lambert carried out the geographical system information (GIS) analysis and performed the PARAFAC model with help of Philippe Massicotte; and Thibault Lambert analyzed the data and drafted the manuscript, which was revised and approved by all co-authors.

Acknowledgements. This work was funded by the Fonds National de la Recherche Scientifique (FNRS, TransCongo, 14711103; FluoDOM J.0009.15), the European Research Council (ERC-StG 240002 AFRIVAL), the Belgian Federal Science Policy (BELSPO, COBAFISH, SD/AR/05A), the Research Foundation Flanders (FWO-Vlaanderen), the Research Council of the KU Leuven, and the Fonds Léopold III pour l'Exploration et la Conservation de la Nature. The freshwater discharge data of the Congo at Kinshasa were kindly provided by the Régie des Voies Fluviales (RVF, DRC). We are grateful for help in sampling from T. Mambo Baba (Université de Kisangani, DRC), and for analytical support from S. Petrovic (University of Liège), B. Leporcq (University of Namur), and Z. Kelemen and C Morana (KU Leuven). We thank the two anonymous reviewers for constructive comments on the previous version of the manuscript. Thibault Lambert and Alberto V. Borges are a postdoctoral researcher and senior research associate, respectively, at the FNRS.

Edited by: T. J. Battin

Reviewed by: two anonymous referees

\section{References}

Baines, S. B. and Pace, M. L.: The production of dissolved organic matter by phytoplankton and its importance to bacteria: patterns across marine and freshwater systems, Limnol. Oceanogr., 36, 1078-1090, 1991.
Bano, N., Moran, M. A., and Hodson, R. E.: Photochemical formation of labile organic matter from two components of dissolved organic carbon in a freshwater wetland, Aquat. Microb. Ecol., 16, 95-102, 1998.

Battin, T. J.: Dissolved organic matter and its optical properties in a blackwater tributary of the upper Oricono river, Venezuela, Org. Geochem., 28, 561-569, 1998.

Battin, T. J., Kaplan, L. A., Findlay, S., Hopkinson, C. S., Marti, E., Packman, A. I., Newbold, J. D., and Sabater, F.: Biophysical controls on organic carbon fluxes in fluvial networks, Nat. Geosci., 1, 95-100, 2008.

Berggren, M., Lapierre, J.-F., and del Giorgio, P. A.: Magnitude and regulation of bacterioplankton respiratory quotient across freshwater environmental gradients, ISME J., 6, 984-993, doi:10.1038/ismej.2011.157, 2012.

Bertilsson, S. and Jones, J. B.: Supply of dissolved organic matter to aquatic ecosystems: autochthonous sources, in: Aquatic ecosystems: interactivity of dissolved organic matter, edited by: Findlay, S. and Sinsabaugh, R. L., Academic Press, 3-24, 2003.

Besemer, K., Luef, B., Preiner, S., Eichberger, B., Agis, M., and Peduzzi, P.: Sources and composition of organic matter for bacterial growth in a large European river floodplain system (Danube, Austria), Org. Geochem., 40, 321-331, 2009.

Bontemps, S., Defourney, P., Van Bogaert, E., and Arino, O.: GLOBCOVER2009 Products Description and Validation Report. (ESA and UCLouvain), available at: http://due.esrin.esa.int/files/ GLOBCOVER2009_Validation_Report_2.2.pdf (last access: 15 September 2015), 2011.

Borcard, D., Gillet, F., and Legendre, P.: Numerical ecology with R, Springer New York, New York, 306 pp., doi:10.1007/978-14419-7976-6, 2011.

Borges, A. V., Darchambeau, F., Teodoru, C. R., Marwick, T. R., Tamooh, F., Geeraert, N., Omengo, F. O., Guerin, F., Lambert, T., Morana, C., Okuku, E., and Bouillon, S.: Globally significant greenhouse-gas emissions from African inland waters, Nat. Geosci., 8, 637-642, doi:10.1038/ngeo2486, 2015 a.

Borges, A. V., Abril, G., Darchambeau, F., Teodoru, C. R., Deborde, J., Vidal, L. O., Lambert, T., and Bouillon, S.: Divergent biophysical controls of aquatic $\mathrm{CO}_{2}$ and $\mathrm{CH}_{4}$ in the World's two largest rivers; Scientific Reports, 5, 15614, doi:10.1038/srep15614, 2015b.

Bouillon, S., Yambélé, A., Spencer, R. G. M., Gillikin, D. P., Hernes, P. J., Six, J., Merckx, R., and Borges, A. V.: Organic matter sources, fluxes and greenhouse gas exchange in the Oubangui River (Congo River basin), Biogeosciences, 9, 2045-2062, doi:10.5194/bg-9-2045-2012, 2012.

Bouillon, S., Yambélé, A., Gillikin, D. P., Teodoru, C. R., Darchambeau, F., Lambert, T., and Borges, A. V.: Contrasting biogeochemical characteristics of the Oubangui River and tributaries (Congo River basin), Scientific Report, 4, 1-10, doi:10.1038/srep05402, 2014.

Bricquet, J. P.: Les écoulements du Congo à Brazzaville et la spatialisation des apports, in Grands Bassins Fluviaux Péri-atlantiques, edited by: Olivry, J. C. and Boulègue, J., Inst. Fr. de Rech. Sci. pour le Dev. en Coop. (ORSTOM), Paris, 27-38, 1995.

Bwangoy, J.-R. B., Hansen, M. C., Roy, D. P., De Grandi, G., and Justice, C. O.: Wetland mapping in the Congo Basin using optical and radar remotely sensed data and derived topographical indices, Remote Sens. Environ., 114, 73-86, 2010. 
Cawley, K. M., Wolski, P., Mladenov, N., and Jaffé, R.: Dissolved organic matter biogeochemistry along a transect of the Okavango delta, Bostwana, Wetlands, 32, 475-486, doi:10.1007/s13157012-0281-0, 2012.

Coble, P. G., Lead, J., Baker, A., Reynolds, D. M., and Spencer, R. G. M.: Aquatic Organic Matter Fluorescence, NY: Cambridge University Press, New York, 375 pp., 2014.

Cole, J. J., Prairie, Y. T., Caraco, N. F., McDowell, W. H., Tranvik, L. J., Striegl, R. G., Duarte, C. M., Kortelainen, P., Downing, J. A., Middelburg, J. J., and Melack, J.: Plumbing the global carbon cycle: integrating inland waters into the terrestrial carbon budget, Ecosystems, 10, 171-184, 2007.

Cory, R. M., McKnight, D. M., Chin, Y. P., Miller, P., and Jaros, C. L.: Chemical characteristics of fulvic acids from Arctic surface waters: Microbial contributions and photochemical transformations, J. Geophys. Res.-Biogeo., 112, G04S51, doi:10.1029/2006JG000343, 2007.

Cory, R. M., Ward, C. P., Crump, B. C., and Kling, G. W.: Sunlight controls water column processing of carbon in arctic freshwaters, Science, 345, 925-928, doi:10.1126/science.1253119, 2014

Cory, R. M., Harrold, K. H., Neilson, B. T., and Kling, G. W.: Controls on dissolved organic matter (DOM) degradation in a headwater stream: the influence of photochemical and hydrological conditions in determining light-limitation or substratelimitation of photo-degradation, Biogeosciences, 12, 6669-6685, doi:10.5194/bg-12-6669-2015, 2015.

Coynel, A., Seyler, P., Etcheber, H., Meybeck, M., and Orange, D.: Spatial and seasonal dynamics of total suspended sediment and organic carbon species in the Congo River, Global Biogeochem. Cy., 19, GB4019, doi:10.1029/2004GB002335, 2005.

Creed, I. F., McKnight, D., Pellerin, B. A., Green, M. B., Bergamaschi, B. A., Aiken, G. R., Burns, D. A., Findlay, S. E. G., Shanley, J. B., Striegl, R. G., Aulenbach, B. T., Clow, D. W., Laudon, H., McGlynn, B. L., McGuire, K. J., Smith, T. A., and Stackpoole, S. M.: The river as a chemostat: fresh perspectives on dissolved organic matter flowing down the river continuum, Can. J. Fish. Aquat. Sci., 72, 1272-1285, doi:10.1139/cjfas-2014-0400, 2015.

Descy, J. P., Darchambeau, F., Lambert, T., Stoyneva, M. P., Bouillon, S., and Borges, A. V.: Phytoplankton dynamics in the Congo River, Freshwater Biol., doi:10.1111/fwb.12851, in press, 2016.

Fasching, C., Behounek, B., Singer, G. A., and Battin, T. J.: Microbial degradation of terrigenous dissolved organic matter and potential consequences for carbon cycling in brown-water streams, Scientific Reports, 4, 4981, doi:10.1038/srep04981, 2014.

Fellman, J. B., Hood, E., and Spencer, R. G. M.: Fluorescence spectroscopy opens new windows into dissolved organic matter dynamics in freshwater ecosystems: A review, Limnol. Oceanogr., 55, 2452-2462, doi:10.4319/lo.2010.55.6.2452, 2010.

Guillemette, F. and del Giorgio, P. A.: Simultaneous consumption and production of fluorescent dissolved organic matter by lake bacterioplankton, Environ. Microbiol., 14, 1432-1443, 2012.

Hanley, K., Wollheim, W. M., Salisbury, J., Huntington, T., and Aiken, G.: Controls on dissolved organic carbon quantity and chemical character in temperate rivers of North America, Global Biogeochem. Cy., 27, 492-504, doi:10.1002/gbc.20044, 2013.

Helms, J. R., Stubbins, A., Ritchie, J. D., Minor, E. C., Kieber, D. J., and Mopper, K.: Absorption spectral slopes and slope ratios as indicators of molecular weight, source, and photobleaching of chromophoric dissolved organic matter, Limnol. Oceanogr., 53, 955-969, 2008.

Ishii, S. K. L. and Boyer, T. H.: Behavior of reoccurring parafac components in fluorescent dissolved organic matter in natural and engineered systems: A critical review, Environ. Sci. Technol. 46, 2006-2017, doi:10.1021/es2043504, 2012.

Jaffé, R., McKnight, D., Maie, N., Cory, R., McDowell, W. H., and Campbell, J. L.: Spatial and temporal variations in DOM composition in ecosystems: The importance of long-term monitoring of optical properties, J. Geophys. Res.-Biogeo., 113, G04032, doi:10.1029/2008jg000683, 2008.

Junk, W., Bayley, P. B., and Sparks, R. E.: The flood pulse concept in river-floodplain systems, Can. Spec. Publ. Fish. Aquat. Sci., 106, 110-127, 1989.

Kellerman, A. M., Kothawala, D. N., Dittmar, T., and Tranvik, L. J.: Persistence of dissolved organic matter in lakes related to its molecular characteristics, Nat. Geosci., 8, 454-457, doi:10.1038/ngeo2440, 2015.

Kothawala, D. N., Stedmon, C. A., Müller, R. A., Weyhenmeyer, G. A., Köhler, S. J., and Tranvik, L. J.: Controls of dissolved organic matter quality: Evidence from a large-scale boreal lake survey, Glob. Change Biol., 20, 1101-1114, doi:10.1111/gcb.12488, 2014.

Lambert, T., Pierson-Wickmann, A.-C., Gruau, G., Thibault, J. N., and Jaffrezic, A.: Carbon isotopes as tracers of dissolved organic carbon sources and water pathways in headwater catchments, J. Hydrol., 402, 228-238, doi:10.1016/j.jhydrol.2011.03.014, 2011.

Lambert, T., Darchambeau, F., Bouillon, S., Alhou, B., Mbega, J.D., Teodoru, C. R., Nyoni, F. C., Massicotte, P., and Borges, A. V.: Landscape control on the spatial and temporal variability of chromophoric dissolved organic matter and dissolved organic carbon in large African rivers, Ecosystems, 18, 1224-1239, doi:10.1007/s10021-015-9894-5, 2015.

Lambert, T., Teodoru, C. R., Nyoni, F. C., Bouillon, S., Darchambeau, F., Massicotte, P., and Borges, A. V.: Along-stream transport and transformation of dissolved organic matter in a large tropical river, Biogeosciences, 13, 2727-2741, doi:10.5194/bg13-2727-2016, 2016.

Lapierre, J.-F. and del Giorgio, P. A.: Partial coupling and differential regulation of biologically and photochemically labile dissolved organic carbon across boreal aquatic networks, Biogeosciences, 11, 5969-5985, doi:10.5194/bg-11-5969-2014, 2014.

Laraque, A., Bricquet, J. P., Pandi, A., and Olivry, J. C.: A review of material transport by the Congo River and its tributaries, Hydrol. Process., 23, 3216-3224, 2009.

Leenheer, J. and Croué, J.: Characterizing aquatic dissolved organic matter, Environ. Sci. Technol., 37, 18-26, 2003.

Lehner, B. and Döll, P.: Development and validation of a global database of lakes, reservoirs and wetlands, J. Hydrol., 296, 1-22, doi:10.1016/j.jhydrol.2004.03.028, 2004.

Lehner, B., Verdin, K., and Jarvis, A.: New global hydrography derived from space borne elevation data, Eos, 89, 93-94, doi:10.1029/2008EO100001, 2008.

Mann, P. J., Spencer, R. G. M., Dinga, B. J., Poulsen, J.R., Hernes, P.J., Fiske, G., Salter, M. E., Wang, Z. A., Hoering, K.A., Six, J., and Holmes, R. M.: The biogeochemistry of carbon across a gradient of streams and rivers within the Congo Basin. J. Geophys Res.-Biogeo., 119, 687-702, 2014. 
Marín-Spiotta, E., Gruley, K. E., Crawford, J., Atkinson, E. E., Miesel, J. R., Greene, S., Cardona-Correa, C., and Spencer, R. G. M.: Paradigm shifts in soil organic matter research affect interpretations of aquatic carbon cycling: transcending disciplinary and ecosystem boundaries, Biogeochemistry, 117, 279297, doi:10.1007/s10533-013-9949-7, 2014.

Massicotte, P. and Frenette, J.-J.: Spatial connectivity in a large river system: resolving the sources and fate of dissolved organic matter, Ecol. Appl., 21, 2600-2617, 2011.

McKnight, D. M., Boyer, E. W., Westerhoff, P. K., Doran, P. T., Kulbe, T., and Andersen, D. T.: Spectrofluorometric characterization of dissolved organic matter for indication of precursor organic material and aromaticity, Limnol. Oceanogr., 46, 38-48, 2001.

Meybeck, M.: Riverine transport of atmospheric carbon: source, global typology and budget, Water Air Soil Poll., 70, 443-463, 1993.

Morana, C., Sarmento, H., Descy, J.-P., Gasol, J. M., Borges, A. V., Bouillon, S., and Darchambeau, F.: Production of dissolved organic matter by phytoplankton and its uptake by heterotrophic prokaryotes in large tropical lakes, Limnol. Oceanogr., 59, 13641375, 2014.

Moreira-Turcq, P., Seyler, P., Guyot, J. L., and Etcheber, H.: Exportation of organic carbon from the Amazon River and its main tributaries, Hydrol. Process., 17, 1329-1344, 2003.

Murphy, K. R., Stedmon, C. A., Graeber, D., and Bro, R.: Fluorescence spectroscopy and multi-way techniques, PARAFAC, Anal. Methods, 5, 6557-6566, 2013.

Neff, J. C., Finlay, J. C., Zimov, S. A., Davydov, S. P., Carrasco, J. J., Schuur, E. A. G., and Davydova, A. I.: Seasonal changes in the age and structure of dissolved organic carbon in Siberian rivers and streams, Geophys. Res. Lett., 33, L23401, doi:10.1029/2006GL028222, 2006.

Ohno, T.: Fluorescence inner-filtering correction for determining the humification index of dissolved organic matter, Environ. Sci. Technol., 36, 742-746, doi:10.1021/Es0155276, 2002.

Osburn, C. L., Retamal, L., and Vincent, W. F.: Photoreactivity of chromophoric dissolved organic matter transported by the Mackenzie River to the Beaufort Sea, Mar. Chem., 115, 10-20, doi:10.1016/j.marchem.2009.05.003, 2009.

Poole, G. C.: Stream hydrogeomorphology as a physical science basis for advances in stream ecology, J. N. Am. Benthol. Soc., 29, 12-25, 2010.

Raymond, P. A., Saiers, J. E., and Sobczak W. V.: Hydrological and biogeochemical controls on watershed dissolved organic matter transport: pulse-shunt concept, Ecology, 97, 5-16, doi:10.1890/14-1684.1, 2016.

Remington, S., Krusche, A., and Richey, J.: Effects of DOM photochemistry on bacterial metabolism and $\mathrm{CO}_{2}$ evasion during falling water in a humic and a whitewater river in the Brazilian Amazon, Biogeochemistry, 105, 185-200, doi:10.1007/s10533010-9565-8, 2011.

Richardson, D. C., Newbold, J. D., Aufdenkampe, A. K., Taylor, P. G., and Kaplan, L. A.: Measuring heterotrophic respiration rates of suspended particulate organic carbon from stream ecosystems, Limnol. Oceanogr.-Meth., 11, 247-261, 2013.

Runge, J.: The Congo River, Central Africa in Large Rivers: Geomorpholgy and Management, edited by: Gupta, A., John Wiley \& Sons, Ltd, 293-309, 2008.
Sanderman, J., Lohse, K. A., Baldock, J. A., and Amundson, R.: Linking soils and streams: sources and chemistry of dissolved organic matter in a small coastal watershed, Water Resour. Res., 45, W03418, doi:10.1029/2008WR006977, 2009.

Spencer, R. G. M., Stubbins, A., Hernes, P. J., Baker, A., Mopper, K., Aufdenkampe, A. K., Dyda, R. Y., Mwamba, V. L., Mangangu, A. M., Wabakanghanzi, J. N., and Six, J.: Photochemical degradation of dissolved organic matter and dissolved lignin phenols from the Congo River, J. Geophys. Res.-Biogeo., 114, G03010, doi:10.1029/2009jg000968, 2009.

Spencer, R. G. M., Hernes, P. J., Ruf, R., Baker, A., Dyda, R. Y., Stubbins, A., and Six, J.: Temporal controls on dissolved organic matter and lignin biogeochemistry in a pristine tropical river, Democratic Republic of Congo, J. Geophys. Res., 115, G03013, doi:10.1029/2009JG001180, 2010.

Spencer, R. G. M., Hernes, P. J., Aufdenkampe, A. K., Baker, A., Gulliver, P., Stubbins, A., Aiken, G. R., Dyda, R. Y., Butler, K. D., Mwamba, V. L., Mangangu, A. M., Wabakanghanzi, J. N., and Six, J.: An initial investigation into the organic matter biogeochemistry of the Congo River, Geochim. Cosmochim. Ac., 84, 614-627, 2012.

Stedmon, C. A. and Markager, S.: Resolving the variability in DOM fluorescence in a temperate estuary and its catchment unsing PARAFAC, Limnol. Oceanogr, 50, 686-697, 2005.

Stedmon, C. A., Markager, S., and Bro, R.: Tracing dissolved organic matter in aquatic environments using a new approach to fluorescence spectroscopy, Mar. Chem., 82, 239-254, doi:10.1016/s0304-4203(03)00072-0, 2003.

Strahler, A. N.: Quantitative analysis of watershed geomorphology, T. Am. Geophys. Un., 38, 913-920, 1957.

Stubbins, A., Lapierre, J. F., Berggren, M., Prairie, Y. T., Dittmar, T., and del Giorgio, P. A.: What's in an EEM? Molecular signatures associated with dissolved organic fluorescence in boreal Canada, Environ Sci. Technol., 48, 10598-10606, 2014.

Tranvik, L. J. and Bertilsson, S.: Contrasting effects of solar UV radiation on dissolved organic sources for bacterial growth, Ecol. Lett., 4, 458-463, 2001.

Vannote, R. L., Minshall, G. W., Cummins, K. W., Sedell, J. R., and Cushing, C. E.: The river continuum concept, Can. J. Fish. Aquat. Sci., 37, 130-137, 1980.

Wagner, S., Jaffé , R., Cawley, K., Dittmar, T., and Stubbins, A.: Associations Between the Molecular and Optical Properties of Dissolved Organic Matter in the Florida Everglades, a Model Coastal Wetland System, Front. Chem., 3, doi:10.3389/fchem.2015.00066, 2015.

Walker, S. A., Amon, R. M., and Stedmon, C. A.: Variations in highlatitude riverine fluorescent dissolved organic matter: A comparison of large Arctic rivers, J. Geophys. Res-Biogeo., 118, 16891702, doi:10.1002/2013JG002320, 2013.

Ward, N. D., Keil, R. G., Medeiros, P. M., Brito, D. C., Cunha, A. C., Dittmar, T., Yager, P. L., Krusche, A. V., and Richey, J. E.: Degradation of terrestrially derived macromolecules in the Amazon River, Nat. Geosci., 6, 530-533, doi:10.1038/ngeo1817, 2013.

Weishaar, J. L., Aiken, G. R., Bergamaschi, B. A., Fram, M. S., Fujii, R., and Mopper, K.: Evaluation of specific ultraviolet absorbance as an indicator of the chemical composition and reactivity of dissolved organic carbon, Environ. Sci. Technol., 37, 47024708, doi:10.1021/es030360x, 2003. 
Weyhenmeyer, G. A., Fröberg, M., Karltun, E., Khalili, M., Kothawala, D., Temnerud, J., and Tranvik, L. J.: Selective decay of terrestrial organic carbon during transport from land to sea, Glob. Change Biol., 18, 349-355, doi:10.1111/j.13652486.2011.02544.x, 2012.

Yamashita, Y., Scinto, L. J., Maie, N., and Jaffé, R.: Dissolved organic matter characteristics across a subtropical wetland's landscape: application of optical properties in the assessment of environmental dynamics, Ecosystems, 13, 1006-1019, doi:10.1007/s10021-010-9370-1, 2010.
Zepp, R. G., Sheldon, W. M., and Moran, M. A.: Dissolved organic fluorophores in southeastern US coastal waters: correction method for eliminating Rayleigh and Raman scattering peaks in excitation-emission matrices, Mar. Chem., 89, 15-36, doi:10.1016/j.marchem.2004.02.006, 2004.

Zurbrügg, R., Suter, S., Lehmann, M. F., Wehrli, B., and Senn, D. B.: Organic carbon and nitrogen export from a tropical dam-impacted floodplain system, Biogeosciences, 10, 23-38, doi:10.5194/bg-10-23-2013, 2013. 